\title{
Transcriptional Profiling of Diffusible Lipopeptides and Fungal Virulence Genes During Bacillus amyloliquefaciens EZ1509-Mediated Suppression of Sclerotinia sclerotiorum
}

\author{
Ayaz Farzand, ${ }^{1,2}$ Anam Moosa, ${ }^{2}$ Muhammad Zubair, ${ }^{1}$ Abdur Rashid Khan, ${ }^{1}$ Muhammad Ayaz, ${ }^{1}$ \\ Venance Colman Massawe, ${ }^{1}$ and Xuewen $\mathrm{Gao}^{1, \dagger}$ \\ ${ }^{1}$ College of Plant Protection, Nanjing Agricultural University, Key Laboratory of Monitoring and Management of Crop Disease and Pest Insects, \\ Ministry of Agriculture, Nanjing 210095, China \\ 2 Department of Plant Pathology, University of Agriculture, Faisalabad, Pakistan \\ Accepted for publication 17 July 2019.
}

\begin{abstract}
Sclerotinia sclerotiorum is a devastating necrotrophic pathogen that infects multiple crops, and its control is an unremitting challenge. In this work, we attempted to gain insights into the pivotal role of lipopeptides (LPs) in the antifungal activity of Bacillus amyloliquefaciens EZ1509. In a comparative study involving five Bacillus strains, B. amyloliquefaciens EZ1509 harboring four LPs biosynthetic genes (viz. surfactin, iturin, fengycin, and bacilysin) exhibited promising antifungal activity against $S$. sclerotiorum in a dualculture assay. Our data demonstrated a remarkable upsurge in LPs biosynthetic gene expression through quantitative reverse transcription PCR during in vitro interaction assay with $S$. sclerotiorum. Maximum upregulation in LPs biosynthetic genes was observed on the second and third days of in vitro interaction, with iturin and fengycin being the highly expressed genes. Subsequently, Matrix-assisted laser desorption/ionization-time of flight-
\end{abstract}

ABSTRAC

Sclerotinia sclerotiorum is a soilborne fungus that causes serious losses to economically important crops worldwide (Boland and Hall 1994). The ability of this fungus to produce sclerotia that serve as survival structures for several years under harsh environment and infection propagules in the soil plays a key role in the pathogenicity (Bloomfield and Alexander 1967). However, oxalic acid produced by this pathogen is well documented to be the primary determinant of its virulence (Bolton et al. 2006; Kim et al. 2008). After successful colonization of the host plant, the pathogen produces cell wall-degrading enzymes (CWDEs) that disintegrate the cell wall and contribute to its virulence (Purdy 1979). S. sclerotiorum produces oxalic acid during early stages of host plant infection that creates an acidic environment and triggers the synthesis of CWDEs that are functionally active at low $\mathrm{pH}$ (Liang et al. 2015; Williams et al. 2011). Oxalic acid induces cell death in host plant supporting the necrotrophic nature of this pathogen. Oxalic acid-deficient mutants of $S$. sclerotiorum showed reduced virulence on host plants, supporting its vital role in pathogenicity (Liang et al. 2015). Therefore, the diverse array of infection structures and compounds produced by this pathogen signifies its importance as a potential threat to crop production.

†Corresponding author: X. Gao; gaoxw@njau.edu.cn

Funding: This research was supported by National Key Research and Development Program of China grant 2017YFD0200400, National Natural Science Foundation of China grant 31471811, and Jiangsu Independent Innovation Fund for Agricultural Science and Technology grant CX(18)1003.

The author(s) declare no conflict of interest.

(c) 2020 The American Phytopathological Society mass spectrometry analysis confirmed the presence of LPs in the inhibition zone. Scanning electron microscope analysis showed disintegration, shrinkage, plasmolysis, and breakdown of fungal hyphae. During in planta evaluation, S. sclerotiorum previously challenged with EZ1509 showed significant suppression in pathogenicity on detached leaves of tobacco and rapeseed. The oxalic acid synthesis was also significantly reduced in $S$. sclerotiorum previously confronted with antagonistic bacterium. The expression of major virulence genes of $S$. sclerotiorum, including endopolygalacturonase-3, oxalic acid hydrolase, and endopolygalacturonase- 6 , was significantly downregulated during in vitro confrontation with EZ1509.

Keywords: disease control and pest management
Several control strategies, such as crop rotation, resistant germplasm, and moisture maintenance, have failed to control this pathogen because of lack of resistant varieties and the survival potential of sclerotia for an indefinite period in the soil. The most frequent control of S. sclerotiorum is through synthetic fungicides. However, the use of chemicals contributes to environmental hazards and health safety concerns (Boland and Hall 1987). Biological control has emerged as a sustainable and effective approach to control plant pathogens (Farzand et al. 2019; Massawe et al. 2018; Minuto et al. 2006). Among biological control agents, Bacillus species are promising bacteria that have been used to control several plant diseases (Hobley et al. 2013; Ongena and Jacques 2008; Stein 2005). The mechanisms through which Bacillus species affect the pathogen development generally include the following: (i) direct antagonism of the pathogen, (ii) competition for food and ecological niche, and (iii) release of toxic antibiotic substances (Whipps 2001). However, the primary mode of action of Bacillus species to suppress plant pathogenic fungi is antibiosis (Romero et al. 2007).

Bacillus species, particularly Bacillus amyloliquefaciens strains, are considered as ecofriendly, with excellent colonization capacity and versatile mode of action to suppress plant pathogens (Zhao et al. 2014). B. amyloliquefaciens dedicates up to $340 \mathrm{~kb}$, which correspond to $8 \%$ of its genomic makeup, to produce a wide range of antimicrobial compounds, such as antibiotics, lytic enzymes, and several nonribosomally synthesized cyclic lipopeptides (LPs) and polyketides (Chen et al. 2009). Among these antimicrobial compounds, LPs have distinguished antimicrobial activity. They have been classified in several families, and among them, surfactin, fengycin, and iturin families are of high interest, because they can be secreted in high amounts under natural growth conditions of the rhizosphere (Debois et al. 2014; Nihorimbere et al. 2012). Surfactin 
shows antimicrobial, antifungal, hemolytic, and antiviral activity by altering biological membrane integrity (Vater et al. 2003; Wang et al. 2011). Surfactin in combination with iturin has showed strong antifungal activity (Maget-Dana et al. 1992). Fengycin exhibited antifungal activity more specifically against filamentous fungi (Liu et al. 2011; Vanittanakom et al. 1986). Bacilysin is also an important LP with antibacterial and antifungal activity (Chen et al. 2009; Wu et al. 2015a, b). These compounds are thus crucial for rhizosphere fitness and biological control potential of Bacillus strains (Cawoy et al. 2015; Raaijmakers et al. 2010; Romero et al. 2007).

Matrix-assisted laser desorption/ionization-time of flight-mass spectrometry (MALDI-TOF-MS) is considered to be a more rapid and accurate tool to study the synthesis of LPs compared with conventional methods. The efficacy of MALDI-TOF-MS to identify cyclic LPs has been well documented (Kim et al. 2010; Vater et al. 2003). In this context, this study was conducted with a goal to emphasize the importance of antibiosis in direct antagonism of S. sclerotiorum and identify antifungal LPs involved in the direct antagonistic activity of $B$. amyloliquefaciens EZ1509 against the fungal pathogen. This work reveals that the LP-producing B. amyloliquefaciens EZ1509 had direct antifungal activity during in vitro confrontation, causing ultrastructural changes in fungal hyphae, reduction in oxalic acid production, and pathogenicity of $S$. sclerotiorum by downregulating the expression of virulence genes.

\section{MATERIALS AND METHODS}

Microbial cultures and growth conditions. S. sclerotiorum and Bacillus strains used in this study were procured from the Laboratory of Biological Control and Bacterial Molecular Biology, Nanjing Agricultural University, Jiangsu, China (Table 1). Bacterial strains were maintained on Luria Bertani (LB) broth with $60 \%$ (vol/vol) glycerol solution at $-80^{\circ} \mathrm{C}$. These cultures of bacterial strains were refreshed in solid LB medium, and then, a single colony was inoculated on liquid LB medium and incubated at $37^{\circ} \mathrm{C}$. S. sclerotiorum culture was preserved in $60 \%$ glycerol and stored at $-80^{\circ} \mathrm{C}$; this culture was refreshed on potato dextrose agar (PDA) plates and incubated for 4 days at $25^{\circ} \mathrm{C}$ for further use.

Screening for antagonistic activity. The inhibitory effect of five Bacillus strains on mycelial growth of S. sclerotiorum was tested in dual culture. A mycelial plug $(0.6 \mathrm{~cm})$ from a 4-day-old culture of $S$. sclerotiorum was placed at the center of the plate containing PDA medium (HiMEDIA, M096). Afterward, $5 \mu \mathrm{l}$ of bacterial suspension from each Bacillus strain having optical density (OD) 2.50 measured at $600 \mathrm{~nm}$ was poured on sterilized

TABLE 1. List of Bacillus strains used in this study

\begin{tabular}{ll}
\hline Strain identification & \multicolumn{1}{c}{ Name } \\
\hline EZ1509 & Bacillus amyloliquefaciens \\
FZB42 & Bacillus amyloliquefaciens \\
168 & Bacillus subtilis \\
NMTD17 & Bacillus sp. \\
LLCG23 & Bacillus wiedmannii \\
\hline
\end{tabular}

filter paper $3 \mathrm{~cm}$ away from the mycelial plug. The plates were incubated at $25^{\circ} \mathrm{C}$ for 4 days, and the diameter of the inhibition zone was recorded. The experiment was repeated three times, with three replicates of each treatment.

PCR amplification of LPs biosynthetic genes from genomic DNA. Genomic DNA from B. amyloliquefaciens EZ1509 was isolated by using a bacterial genomic DNA extraction kit (OMEGA Bio-tek) according to the manufacturer's manual. The concentration and purity of DNA were measured on NanoDrop 1000 (Thermo Scientific). DNA was amplified based on specifically designed primers for antifungal LP genes (viz. surfactin, iturin, fengycin, and bacilysin) (Table 2). The specificity of the primers was checked through NCBI nucleotide BLAST tools (https:// www.ncbi.nlm.nih.gov/). PCR amplification of genomic DNA was carried out by using $2 \times$ Rapid taq Mater mix (Vazyme) as per the manufacturer's protocol. The PCR conditions were as follows: initial denaturation at $95^{\circ} \mathrm{C}$ for $5 \mathrm{~min}$, including 32 cycles of denaturation at $95^{\circ} \mathrm{C}$ for $15 \mathrm{~s}$, annealing at $55^{\circ} \mathrm{C}$ for $15 \mathrm{~s}$, extension at $72^{\circ} \mathrm{C}$ for $30 \mathrm{~s} / \mathrm{kb}$, and a final extension at $72^{\circ} \mathrm{C}$ for $5 \mathrm{~min}$. A negative control (without DNA) was also included in a PCR reaction. Amplified PCR product from each reaction was visualized on $1 \%$ agarose gel stained with ethidium bromide.

In vitro interaction assay. Antagonism of $B$. amyloliquefaciens EZ1509 against $S$. sclerotiorum was assessed by the previously described method of Johnson and Curl (1972). A 0.6-cm mycelial plug from the margins of an actively growing 4-day-old culture of $S$. sclerotiorum was placed at the center of the plate containing PDA medium. B. amyloliquefaciens EZ1509 $\left(\mathrm{OD}_{600}=2.5\right)$ was streaked at a $3-\mathrm{cm}$ distance from the $S$. sclerotiorum mycelial plug on both sides of the fungal plug and incubated in dark at $25^{\circ} \mathrm{C}$ for 4 days. In the control treatment, a mycelial plug of $S$. sclerotiorum was placed at the center of the plate containing PDA medium without the genus Bacillus. Each treatment was replicated three times, and the experiment was repeated three times.

Extraction of LPs from solid PDA medium. The production of LPs by B. amyloliquefaciens EZ1509 on solid PDA media during coculturing with $S$. sclerotiorum was examined following a predescribed protocol of Torres et al. (2016). Briefly, 1-cm blocks of PDA medium were taken from the inhibition zone close to the bacterial colony (ZCBC) and from the inhibition zone close to the fungal colony ( $\mathrm{ZCFC}$ ), and they were resuspended in $1 \mathrm{ml}$ of acetonitrile. Samples for control were taken from plates containing bacterial antagonist without fungal pathogen. Samples were shaken vigorously for $1 \mathrm{~min}$ and centrifuged at 7,000 rpm for $5 \mathrm{~min}$. The samples were dried in a speed vacuum evaporator (Labogene Aps indusfrivj 6.8 DK-3540 Lynge), redissolved in $50 \mu \mathrm{l}$ of acetonitrile, and saved for MALDI-TOF analysis. The experiment was repeated three times, with three replicates of each treatment.

MALDI-TOF-MS. Mass spectra of LP extracts from solid PDA medium during coculturing were obtained through the BrukerDaltonic instrument (MALDI-TOF-MS) at positive ion mode. The samples were first dried on a stainless steel target plate under a lamp for recording mass spectra using 2,5-dihydroxybenzoic acid as matrix solution. The voltage of reflector was set at $20 \mathrm{kV}$, and laser excitation was carried out at $337 \mathrm{~nm}$ with 80 shots.

TABLE 2. Primers used to amplify lipopeptides biosynthetic genes through PCR

\begin{tabular}{lccc}
\hline Lipopeptides & Melting temperature & Size (base pairs) & Primers \\
\hline Surfactin & 56.3 & 1,298 & CGGTGATCTTGCGAAGCTTTAT \\
Fengycin & 56.3 & 1,447 & CGCTTTCGTTCTGCCATTCT \\
Iturin & 55.9 & 1,244 & CGGCCATTCGCTCATCTTTAT \\
Bacilysin & 52.8 & 657 & GTTTCCGCTTCATCAGTCTCTTC \\
& & & ACCTCACCTTGATCGGCTATAC \\
& & TGGTGGGCGAAGAATTATG \\
\hline
\end{tabular}


Ultrastructural changes in $S$. sclerotiorum mycelium. Ultrastructural changes in S. sclerotiorum mycelium because of biocontrol activity of B. amyloliquefaciens EZ1509 were studied through scanning electron microscope (SEM) analysis (Sharma and Sharma 2008). An $\sim 0.6-\mathrm{cm}$ block of fungal mycelium with a thin PDA medium layer was excised from the edge of the inhibition zone, and the sample for control was taken from the edge of mycelial growth without bacterial antagonist. Both samples were placed in $2.5 \%$ ( $\mathrm{vol} / \mathrm{vol}$ ) glutaraldehyde solution prepared in $0.05 \mathrm{M}$ phosphate buffer ( $\mathrm{pH} 7.2)$ and incubated for $24 \mathrm{~h}$ at $4^{\circ} \mathrm{C}$ after fixation. Later, mycelial growth was washed with the same buffer and dehydrated with a serial dilution of ethanol (30 min for each dilution) followed by dehydration in absolute ethanol for $24 \mathrm{~h}$. The samples were mounted over stubs with gummy carbon tape followed by gold coating for 3 to 4 min with a vacuum ion sputter coater. The samples in three replicates were examined at different magnifications $(20 \mathrm{kV})$ under a scanning electron microscope $(\mathrm{H}-$ 7650; Hitachi).

Pathogenicity assay on detached leaves. The pathogenicity of S. sclerotiorum preexposed to B. amyloliquefaciens EZ1509 during antagonism assay was tested on detached leaves. A fungal mycelial plug of $0.6 \mathrm{~cm}$ was taken from the margin of the inhibition zone after exposing fungal mycelia to antagonist for 4 days and placed on one side of the detached leaves of rapeseed and tobacco. The leaves in control treatment were inoculated with a $0.6-\mathrm{cm}$ block from 4-day-old fungal cultures without bacterial antagonist. The petioles were wrapped with cotton wools to maintain turgidity. The leaves were placed in square petri plates $(10 \times 10 \mathrm{~cm})$ and incubated at $25^{\circ} \mathrm{C}$ with a 12 -h photoperiod cycle. Pathogenicity of S. sclerotiorum was evaluated by measuring the lesion diameter. The experiment was repeated three times, with three replicates of each treatment in a completely randomized design.

Effect of B. amyloliquefaciens EZ1509 on oxalic acid production. To assess the production of oxalic acid, PDA plates were amended with bromophenol blue as an indicator, which emits blue color at $\mathrm{pH} \geq 4.6$ and yellow color at $\mathrm{pH} \leq 4.6$ (Steadman et al. 1994). To investigate the effect of B. amyloliquefaciens EZ1509 on the production of oxalic acid by $S$. sclerotiorum preexposed to bacterial antagonist during antagonism assay, mycelial plugs $(0.6 \mathrm{~cm})$ were taken from the fungal colony from the edge of inhibition zone and transferred to bromophenol blue-amended PDA plates. These plates were incubated at $25^{\circ} \mathrm{C}$ for $72 \mathrm{~h}$. Oxalic acid production was recorded by measuring the diameter of the acidification zone (yellow color) after every $24 \mathrm{~h}$ in three replicates of each treatment, and the experiment was repeated three times.

RNA extraction and quantitative reverse transcription PCR analysis of LPs biosynthetic and virulence genes during antagonism assay. To confirm the expression of LP genes during coculturing, total RNA was extracted from three replicate plates on each day up to 4 days in dual-culture assay including B. amyloliquefaciens EZ1509 and fungus during antagonism. The RNA for control samples was extracted using the bacterial RNA kit (OMEGA) as per the manufacturer's guidelines from three replicate plates, on which bacteria were cultured without fungal pathogen. The expression of major genes involved in virulence of $S$. sclerotiorum was studied by extracting the RNA from fungal mycelium on the fourth day of dual-culture assay with B. amyloliquefaciens EZ1509. Total RNA was extracted from three replicates of dual-culture assay including $S$. sclerotiorum mycelia and B. amyloliquefaciens EZ1509 during antagonism at $96 \mathrm{~h}$ postinoculation, and the RNA for control samples was extracted from three replicate plates on which $S$. sclerotiorum was grown without bacterial antagonist by using Takara RNAiso Reagent (Takara Biotechnology Co.) as per the manufacturer's instructions. The concentration and purity of the RNA were determined by measuring the absorbance at 260/280 nm (NanoDrop 1000; Thermo Scientific). The complementary DNA (cDNA) first strand was synthesized using $5 \times$ All-In-One Rt MasterMix with the
AccuRT genomic DNA Removal Kit (ABM). The synthesized cDNA was used as a template for quantitative reverse transcription PCR (qRT-PCR).

qRT-PCR study of gene expression using SYBR Green. The qRT-PCR analysis was carried out in a QuantStudio RealTime Thermocycler (Thermo Fisher Scientific) using chamQ SYBR green qRT-PCR Master mix (Vayzyme) following the manufacturer's manual. Specific primers for the expression of LPs genes (fengycin, iturin, bacilysin, and surfactin) and virulence genes in $S$. sclerotiorum were designed to conduct qRT-PCR analysis (Table 3 ). The primers for iturin gene were designed using B. amyloliquefaciens CAU B946 iturin gene sequence as a reference, whereas B. amyloliquefaciens FZB42 genome was used for designing the primers of bacilysin, surfactin, and fengycin. The $R P S J$ and actin gene already reported as housekeeping genes were used as internal controls for B. amyloliquefaciens EZ1509 and S. sclerotiorum, respectively (Silva et al. 2009; Jordan et al. 2006). Quantitative real-time PCR was carried out in a 20- $\mu$ l reaction volume containing $10 \mu$ l of $2 \times$ SYBR premix Ex Taq (Til RNaseH Plus) with $0.4 \mu \mathrm{l}$ of Rox as a reference dye, $0.4 \mu \mathrm{l}$ of forward and reverse primers $(20 \mathrm{nmol}), 2 \mu \mathrm{l}$ of cDNA (100 ng), and $6.8 \mu \mathrm{l}$ of double distilled water. The expression was recorded at the following conditions: (1) initial denaturation at $95^{\circ} \mathrm{C}$ for $30 \mathrm{~s}$ and (2) 40 cycles of $95^{\circ} \mathrm{C}$ for $10 \mathrm{~s}$ and $30 \mathrm{~s}$ at $60^{\circ} \mathrm{C}$. The final relative expression of the target genes in three replicates was quantified using ${ }^{\Delta \Delta} \mathrm{Ct}$ (Livak and Schmittgen 2001).

Statistical analysis. In vitro assays were performed in a completely randomized design. Data on in vitro antagonism assay, oxalic acid production test, detached leaf assay, and virulence gene expression were subjected to one-way analysis of variance (ANOVA), whereas LPs biosynthetic gene expression was subjected to two-way ANOVA using statistical package SPSS version 20.0. Treatment means were separated using Tukey's honestly significant difference at $P \leq 0.05$ after ANOVA and are expressed as means \pm standard error of the mean.

TABLE 3. Oligonucleotides used in this study for quantitative reverse transcription PCR analysis

\begin{tabular}{|c|c|}
\hline Oligo name & Sequence $5^{\prime}$ to $3^{\prime}$ \\
\hline Iturin $\mathrm{F}$ & GAGTTCCGCTTCAGCATCTT \\
\hline Iturin $\mathrm{R}$ & AGTCTCCGTAGGCCCATATAC \\
\hline Fengycin F & GTCGCAGAGCTTCAGAGAAA \\
\hline Fengycin R & GATGGACCGTCAGAAACAAGTA \\
\hline Bacilysin F & CTGTCGGAGATGTCACAAGAA \\
\hline Bacilysin R & CGGCTTTCAGGCGTTTAATATC \\
\hline Surfactin F & GAACGCTATAAACGCGATGTG \\
\hline Surfactin R & ATGATTGCTCCAGACGAGATAC \\
\hline RPSJ F & GAAACGGCAAAACGTTCTGG \\
\hline RPSJ R & GTGTTGGGTTCACAATGTCG \\
\hline SSPG $6 \mathrm{~F}$ & AAACAGCATGCACTGCTTCA \\
\hline SSPG $6 \mathrm{R}$ & TCAGCACAATTGCTGTCGAG \\
\hline SSPG $3 \mathrm{~F}$ & CGCACACAACAGTGATGGAT \\
\hline SSPG $3 \mathrm{R}$ & GAACAGGCCATTCCGGTTAC \\
\hline CBH F & ATCGGAGCTCGATCAACTGT \\
\hline CBH R & GTCCAGCATCCTGTCCGATA \\
\hline ASPS F & CCACCAAATTCACCGTTGGT \\
\hline ASPS R & TCGGCCAACATAAGAGTGGT \\
\hline OAH Fa & GCGCTCCAACAACTTGGTTA \\
\hline OAH R & CAGTCTTTGCAGCCATCTCC \\
\hline BXYL F & GCAGCTGGCTCGAATTACTC \\
\hline BXYL R & GTGGATCAATGCGTCGTCAA \\
\hline$\beta$-GLU F & GATCGGACCCGTGATTGTTG \\
\hline$\beta$-GLU R & CGTCCGTGAGAGAATTTCCG \\
\hline GLUCAN F & TGTGTGCCTTCCCATCTCTT \\
\hline GLUCAN R & TGCAGACTGTAGCCAATCCA \\
\hline ACIDP F & TCCGCATACGTTGTCTACGA \\
\hline ACIDP R & GCTGTTGCTGCATTGGAAAC \\
\hline ACTIN F & CAACGATTGAGCGAGGATACA \\
\hline ACTIN R & CGACAAGATGAGGTTGGAAGAG \\
\hline
\end{tabular}

${ }^{a} \mathrm{OAH}$, oxaloacetate hydrolase. 


\section{RESULTS}

Screening for antagonistic activity. Dual-culture screening of five Bacillus strains revealed that B. amyloliquefaciens EZ1509 produced the largest inhibition zone against $S$. sclerotiorum followed by FZB42 and NMTD17 (Fig. 1). Strain LLCG23 showed the lowest inhibition, whereas strain 168 completely failed to inhibit the growth of the pathogen. Based on statistical analysis, all strains differed significantly from each other except for strain 168 and control. Based on dual-culture assay, B. amyloliquefaciens EZ1509 was used for additional antifungal assays against $S$. sclerotiorum.

PCR amplification of antifungal LPs biosynthetic genes in EZ1509. PCR amplification of LPs biosynthetic genes (viz. fengycin, surfactin, iturin, and bacilysin) in the genome of $B$. amyloliquefaciens EZ1509 indicated the presence of all LPs biosynthetic genes (Fig. 2).

Expression of antifungal LPs biosynthetic genes during antagonism. The relative expression of antifungal LPs biosynthetic genes (fengycin, iturin, bacilysin, and surfactin) is presented in Figure 3. Gene expression was studied on 4 consecutive days during dual-culture assay after every $24 \mathrm{~h}$. The expression pattern of LPs genes in B. amyloliquefaciens EZ1509 varied from day 1 to day 4 . All LPs biosynthetic genes showed the highest upregulation on the second day during antagonism assay, but the expression was significantly decreased on the third and fourth days. The expression of genes showed variation in a time-dependent manner. Iturin showed the highest expression compared with other LPs biosynthetic genes on the first and second days of interaction, whereas on the third and fourth days, fengycin showed the highest expression compared with control. Overall, expression of LPs genes was higher than control on all days during coculturing.

Characterization of LPs through MALDI-TOF-MS. MALDI-TOF-MS analysis of LPs extracts from solid PDA medium allowed characterization of LPs involved in antifungal activity of B. amyloliquefaciens EZ1509 against $S$. sclerotiorum. Mass spectra signals confirmed the presence of three major LPs families (viz. surfactin, fengycin, and iturin homologs) in both LPs extracts (Fig. 4). Two homologs of surfactin were detected at $\mathrm{m} / \mathrm{z}$ 1,037.50 [M+ $\mathrm{H}]^{+}$and $1,058.65[\mathrm{M}+\mathrm{Na}]^{+}$from the $\mathrm{ZCBC}$, whereas it was observed at $1,030.58[\mathrm{M}+\mathrm{Na}]^{+}, 1,058.65[\mathrm{M}+\mathrm{Na}]^{+}$, and 1,088.65 $[\mathrm{M}+\mathrm{K}]^{+}$from the ZCFC. Iturin was identified at three different masses $\left(1,081.61[\mathrm{M}+\mathrm{K}]^{+}, 1,109.56[\mathrm{M}+\mathrm{K}]^{+}\right.$, and 1,123.58
$[\mathrm{M}+\mathrm{K}]^{+}$) in the $\mathrm{ZCBC}$, whereas it was characterized at $\mathrm{m} / \mathrm{z}$ $1,081.61[\mathrm{M}+\mathrm{Na}]^{+}$and $1,102.67[\mathrm{M}+\mathrm{H}]^{+}$in the ZCFC. Moreover, fengycin peaks were identified at 1,501.80 $[\mathrm{M}+\mathrm{K}]^{+}$and 1,499.81 $[\mathrm{M}+\mathrm{Na}]^{+}$in both the ZCBC and the ZCFC, respectively. However, bacilysin was not detected in both samples. LPs were identified by comparing their masses with previously reported masses of respective compounds in the literature (Table 4).

Ultrastructural changes in $S$. sclerotiorum. The effect of LP-producing B. amyloliquefaciens EZ1509 on the morphology of $S$. sclerotiorum was assessed during dual-culture assay. B. amyloliquefaciens EZ1509 caused ultrastructural abnormalities

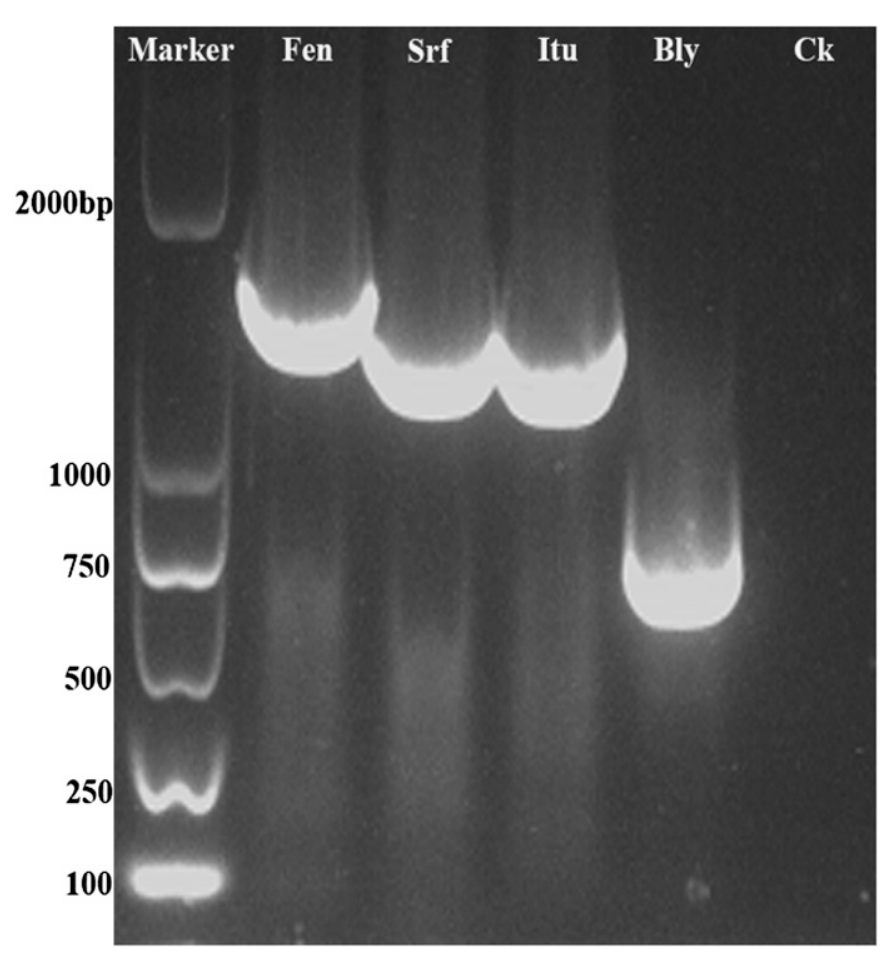

Fig. 2. PCR amplification of antifungal lipopeptide genes in Bacillus amyloliquefaciens EZ1509. Bly, bacilysin; CK, control (without DNA); Fen, fengycin; Itu, iturin; Srf, surfactin.
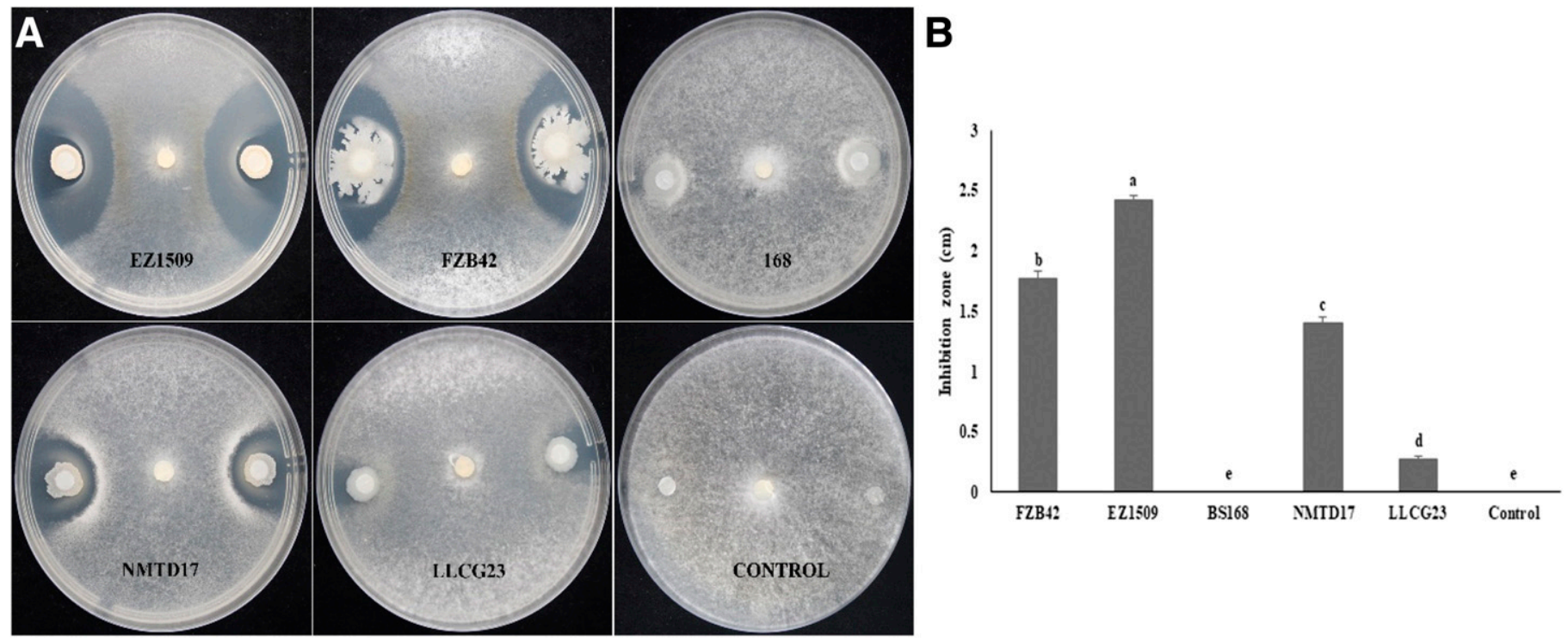

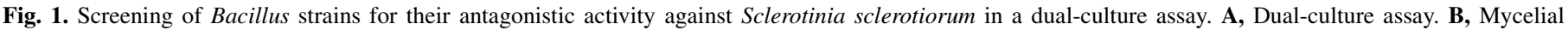

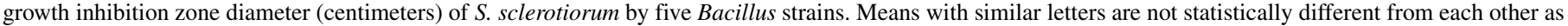
analyzed by Tukey's honestly significant difference test at $P \leq 0.05$. Error bars represent standard error \pm standard error of the mean. 
in the mycelium of $S$. sclerotiorum that were observed through a scanning electron microscope after 4 days of incubation. SEM analysis indicated mycelial deformities, such as plasmolysis, disintegration, shrinkage, and breakdown of fungal hyphae, compared with control. In the control treatment, the mycelium was healthy, round, and cylindrical. The effect of B. amyloliquefaciens EZ1509 on S. sclerotiorum hyphae is presented in Figure 5.

Detached leaf assay. Pathogenicity of S. sclerotiorum was assessed in a detached leaf assay on tobacco and rapeseed. $S$. sclerotiorum previously exposed to B. amyloliquefaciens EZ1509 suppressed the lesions development on tobacco and rapeseed leaves (Fig. 6).

Oxalic acid production test. The effect of $B$. amyloliquefaciens EZ1509 on the production of oxalic acid by S. sclerotiorum was tested on PDA plates amended with bromophenol blue (Fig. 7). After 24 hours postinoculation (hpi), control (untreated) plates produced more yellow color compared with treated plates,

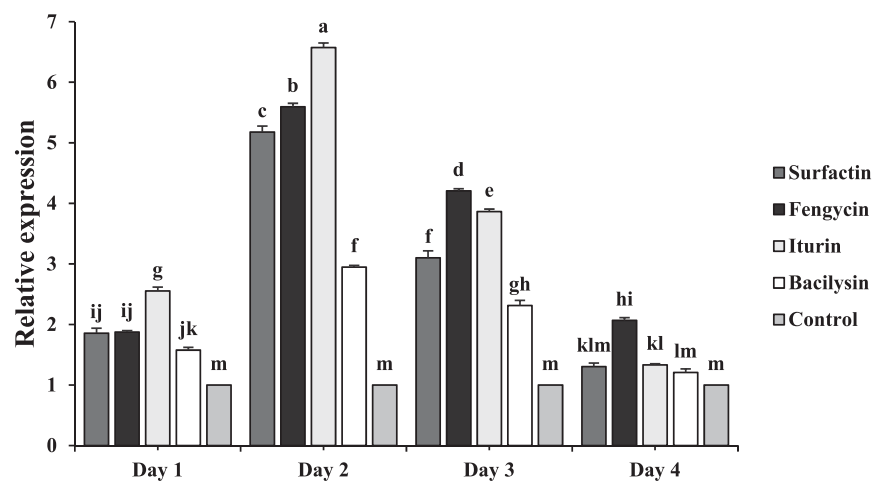

Fig. 3. Expression profile of potent lipopeptide biosynthetic genes in Bacillus amyloliquefaciens EZ1509 during coculturing. Means with similar letters are not statistically different from each other as analyzed by Tukey's honestly significant difference test at $P \leq 0.05$. Error bars represent standard error \pm standard error of the mean. indicating the production of oxalic acid by the pathogen. After $72 \mathrm{hpi}$, control plates turned completely yellow. However, bacteria-treated $S$. sclerotiorum plates showed less depletion in blue color.

Expression of virulence genes in S. sclerotiorum by qRT-PCR. The relative expression of major virulence genes of $S$. sclerotiorum during in vitro interaction assay with B. amyloliquefaciens EZ1509 is shown in Figure 8. Results revealed that $B$. amyloliquefaciens EZ1509 downregulated the expression of all studied virulence genes. Among nine virulence genes, endopolygalacturonase 3 (SSPG3), oxaloacetate hydrolase (OAH), endopolygalacturonase 6 (SSPG6), and cellobiohydrolase were the highly affected genes compared with control.

\section{DISCUSSION}

Several members of the genus Bacillus are antagonistic to plant pathogens and can be used as potential biological control agents (Emmert and Handelsman 1999). Bacillus species use antibiosis as the primary mode of action to suppress fungal pathogens (Chowdhury et al. 2015; Zokaeifar et al. 2014) and produce a diverse group of antimicrobial LPs that differ in mechanism of action, molecular mass, biochemical features, and genetic makeup (Velho et al. 2011). Their antagonistic effect is mainly attributed to the production of antifungal LPs (Susi et al. 2011). Dual-culture assay has been widely used to investigate direct antagonism of biological control agents (Arrebola et al. 2010; Farzand et al. 2019; Torres et al. 2016; Zhang et al. 2012). In this study, B. amyloliquefaciens EZ1509 emerged as the most promising antifungal strain among five Bacillus strains. In vitro suppression of radial growth of $S$. sclerotiorum has been reported previously (Rahman et al. 2016; Sharma and Sharma 2008; Souto et al. 2004; Yang et al. 2009). The formation of inhibition zones to suppress target pathogens was the result of excretion of antimicrobial compounds produced by Bacillus species (Kumar et al. 2012). Among antimicrobial compounds, antifungal LPs are regarded as the key components of Bacillus species involved in the direct

B

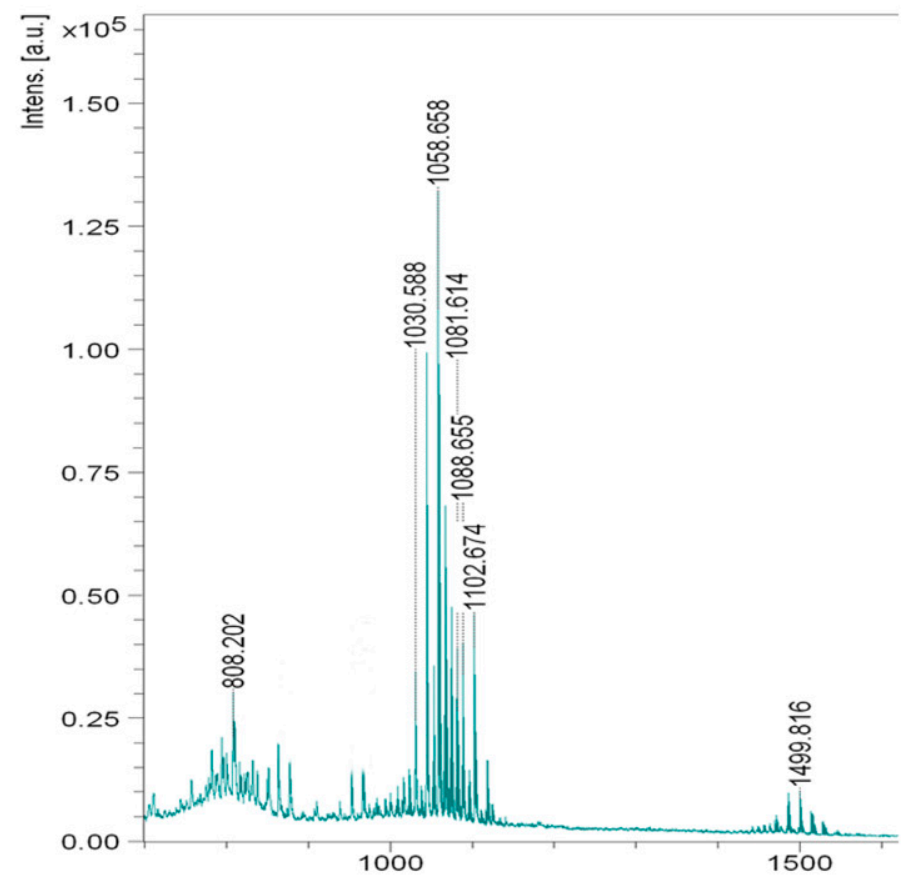

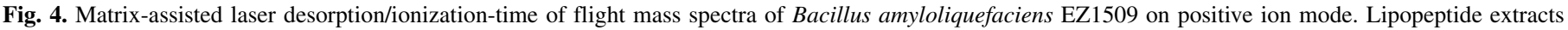
from $\mathbf{A}$, the inhibition zone close to the bacterial colony and $\mathbf{B}$, the inhibition zone close to the fungal colony near the inhibition zone. 
antagonism of fungal pathogens (Cawoy et al. 2015). In this work, we have confirmed the presence of four antifungal LPs biosynthetic genes (viz. surfactin, fengycin, iturin, and bacilysin) producing genes in the genome of B. amyloliquefaciens EZ1509 through PCR amplification of respective genes. Previously, PCR detection methods have been used to confirm the presence of biosynthetic genes encoding surfactin, fengycin, iturin, bacilysin, and difficidin in the genus Bacillus (Rahman et al. 2016).

Bacillus species upregulate the expression of LPs biosynthetic genes during direct antagonism assay (Grabova et al. 2016; Sajitha and Dev 2016; Zihalirwa Kulimushi et al. 2017). It strengthens the fact that the genus Bacillus suppresses the growth of pathogens using LPs as a major weapon contributing to its inhibitory effect. In our previous study, we have reported the antifungal activity of LPs extracted from B. amyloliquefaciens EZ1509 against $S$. sclerotiorum (Farzand et al. 2019). LPs gene expression during antagonism assay involving S. sclerotiorum and B. amyloliquefaciens EZ1509 was studied by qRT-PCR on each day. All studied antifungal LPs biosynthetic genes were differentially expressed from day 1 to day 4. According to a report, surfactin, fengycin, and bacilysin biosynthetic genes showed differential expression during antagonism of Bacillus subtilis B1 against Lasiodiplodia theobromae (Sajitha and Dev 2016). In another instance, the expression of LPs genes encoding surfactin, fengycin, iturin, bacillomycin, bacilysin, and mycosubtilin was recorded through qRT-PCR in a dual-culture assay involving B. subtilis B1 and $L$. theobromae (Sajitha et al. 2016). In our study, fengycin and iturin genes were the most highly induced by the presence of fungus. Gene expression and subsequent synthesis of fengycin and iturin have been associated with antagonism of Bacillus strains (Grabova et al. 2016). We found that the bacilysin gene was expressed on the first day of antagonism assay, contrary to the study of Sajitha and Dev (2016) reporting that bacilysin gene was expressed on the fourth and fifth days of antagonism assay. In this study, surfactin gene was expressed at all days during coculturing, confirming earlier reports (Sajitha and Dev 2016). In an attempt to study the expression of LPs biosynthetic genes, Cawoy et al. (2014) reported the highest gene expression of fengycin on the fourth day of antagonism assay. However, in our study, fengycin showed highest expression on the second day of antagonism assay. The expression of genes kept decreasing on the third and fourth days. The decrease in gene expression might be because it is directly related to messenger RNA (mRNA) produced in bacteria, and the rapid fall in gene expression on later days is because of mRNA decay, which serves continuously to adjust the message according to the needs of cells for a specific protein (Condon 2003; Deutscher 2006).

Bacillus and Pseudomonas species have the potential to fine tune their strategy to produce different antibiotics on interaction with a particular pathogen (Garbeva et al. 2011; Li et al. 2014; Zhu et al. 2013). The production of antifungal LPs from whole-cell surface extracts of Bacillus species has been previously reported through MALDI-TOF-MS (Athukorala et al. 2009; Vater et al. 2002). In this study, MALDI-TOF-MS confirmed the presence of surfactin, iturin, and fengycin in the inhibition zone. The production of LPs in growth medium by $B$. subtilis B1 in coculture with $L$. theobromae has been documented (Sajitha et al. 2016). Surfactin, fengycin, and iturin produced by $B$. subtilis were previously detected in the inhibition zone during dual-culture assay through ultravioletMALDI-TOF (Torres et al. 2016). Bacilysin was not detected in bacterial crude extract through MALDI-TOF-MS. This could be because of the fact that MALDI-TOF-MS is less sensitive to detection of smaller molecules (<500 Da); therefore, bacilysin, which is a low-molecular weight compound (271 Da), cannot be detected through MALDI-TOF-MS analysis (Pan et al. 2007).

Bacillus strains coproducing three LPs (surfactin, fengycin, and iturin) are globally the most antifungal strains (Cawoy et al. 2014), and the synergistic effect of LPs has been reported against several pathogens (Maget-Dana et al. 1992; Ongena et al. 2007; Romero et al.2007). The antifungal effect of iturin is reported to be primarily based on pore formation in biological membranes that causes osmotic perturbation (Maget-Dana and Peypoux 1994). Iturin makes an association with biological membranes, anchors into lipid bilayers, generates irreversible pores by the insertion of surfactin molecules, and acts synergistically with surfactin to cause membrane disruption and solubilization (Ongena and Jacques 2008; Malfanova et al. 2012). Surfactin is the most commonly characterized LP, with excellent surface and membrane active properties and emulsifying and foaming effects (Vater et al. 2002). Surfactin-producing Bacillus strains exhibit high swarming motility and biofilm formation that ultimately facilitates bacterial cell motion. Fengycin has been reported to show high antifungal and antibacterial effect (Kim et al. 2004), particularly against filamentous fungi (Hofemeister et al. 2004; Vanittanakom et al. 1986). Fengycin interacts with lipid bilayers, and it causes

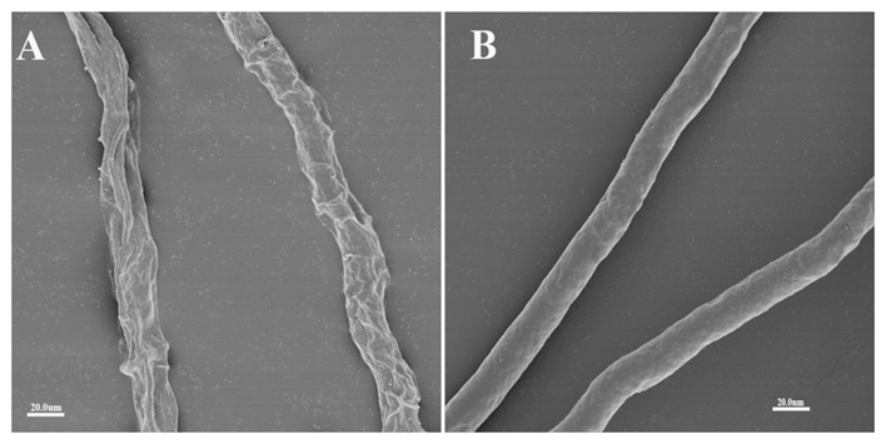

Fig. 5. Ultrastructural changes in Sclerotinia sclerotiorum mycelium under a scanning electron microscope. A, Treated. B, Control.

TABLE 4. Major peaks of lipopeptides produced by Bacillus amyloliquefaciens EZ1509 on solid media against Sclerotinia sclerotiorum characterized by Matrixassisted laser desorption/ionization-time of flight-mass spectrometry

\begin{tabular}{|c|c|c|c|c|c|}
\hline Lipopeptide & Mode & Reported mass & Reference & \multicolumn{2}{|c|}{ Experimental mass } \\
\hline Surfactin & {$[\mathrm{M}+\mathrm{Na}]^{+}$} & $1,030.64$ & Dimkić et al. 2017 & $-^{\mathrm{b}}$ & $1,030.58$ \\
\hline Surfactin & {$[\mathrm{M}+\mathrm{Na}]^{+}$} & $1,058.71$ & Torres et al. 2016 & $1,058.65$ & $1,058.65$ \\
\hline Surfactin & {$[\mathrm{M}+\mathrm{K}]^{+}$} & $1,088.68$ & Torres et al. 2016 & - & $1,088.65$ \\
\hline Iturin & {$[\mathrm{M}+\mathrm{Na}]^{+}$} & $1,081.54$ & Torres et al. 2016 & $1,081.61$ & $1,081.61$ \\
\hline Iturin & {$[\mathrm{M}+\mathrm{H}]^{+}$} & $1,102.51$ & Torres et al. 2016 & - & $1,102.67$ \\
\hline Fengycin & {$[\mathrm{M}+\mathrm{Na}]^{+}$} & $1,499.80$ & Dimkić et al. 2017 & - & $1,499.81$ \\
\hline Fengycin & {$[\mathrm{M}+\mathrm{K}]^{+}$} & $1,501.80$ & Vater et al. 2002 & $1,501.80$ & - \\
\hline
\end{tabular}

${ }^{a} \mathrm{ZCBC}$, samples extracted from the inhibition zone close to the bacterial colony; ZCFC, samples extracted from the inhibition zone close to the fungal colony.

${ }^{\mathrm{b}}$ Dashes indicate mass not detected. 
membrane solubilization, alters membrane structure and permeability, and creates ion-conducting channels in biological membranes (Deleu et al. 2005). Therefore, the coproduction of surfactin, fengycin, and iturin might be a cause of the strong antifungal activity of B. amyloliquefaciens EZ1509.

SEM revealed visible ultrastructural changes in $S$. sclerotiorum hyphae previously challenged with B. amyloliquefaciens EZ1509.
The ability of B. amyloliquefaciens EZ1509 to produce antifungal LPs could explain the observed results. It has been documented that antifungal LPs alter the ultrastructure of biological membranes, which leads to leakage of cellular metabolites and results in cell death (Brogden 2005). Similar ultrastructural changes in S. sclerotiorum hyphae during dual-culture interaction have been observed previously by Kamal et al. (2016). Sajitha and Dev
A

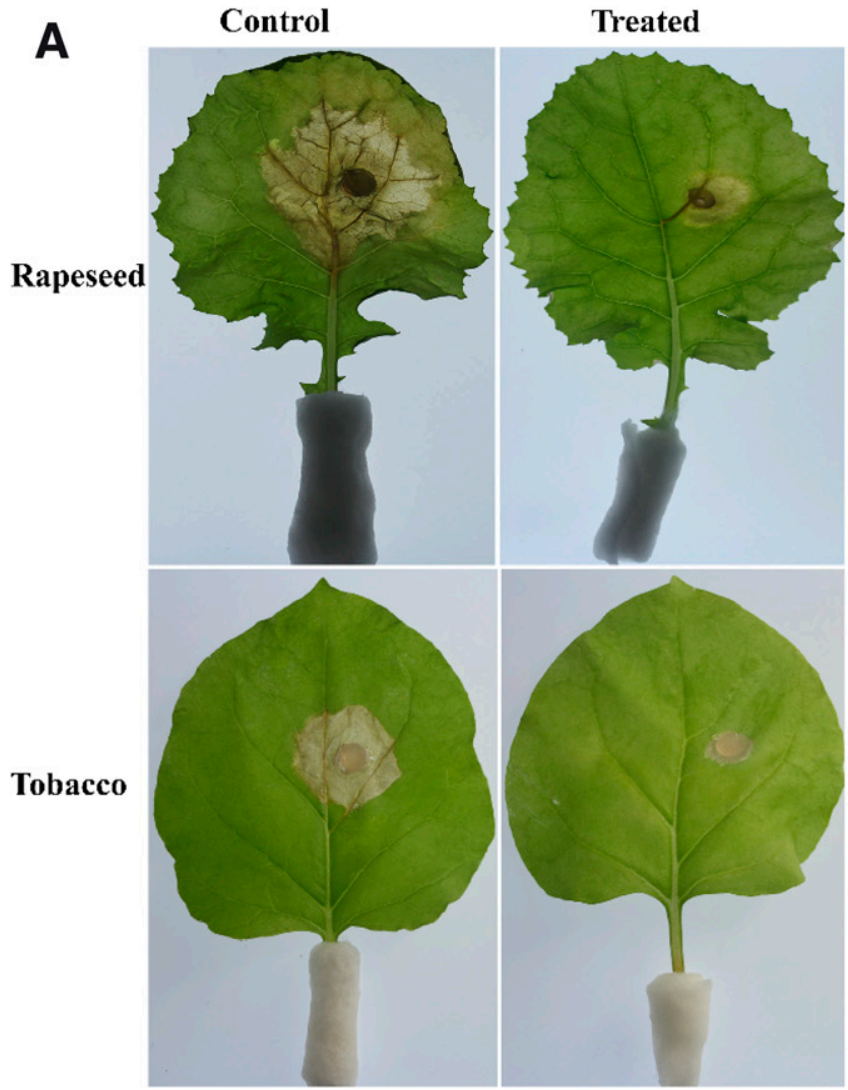

Tobacco
B

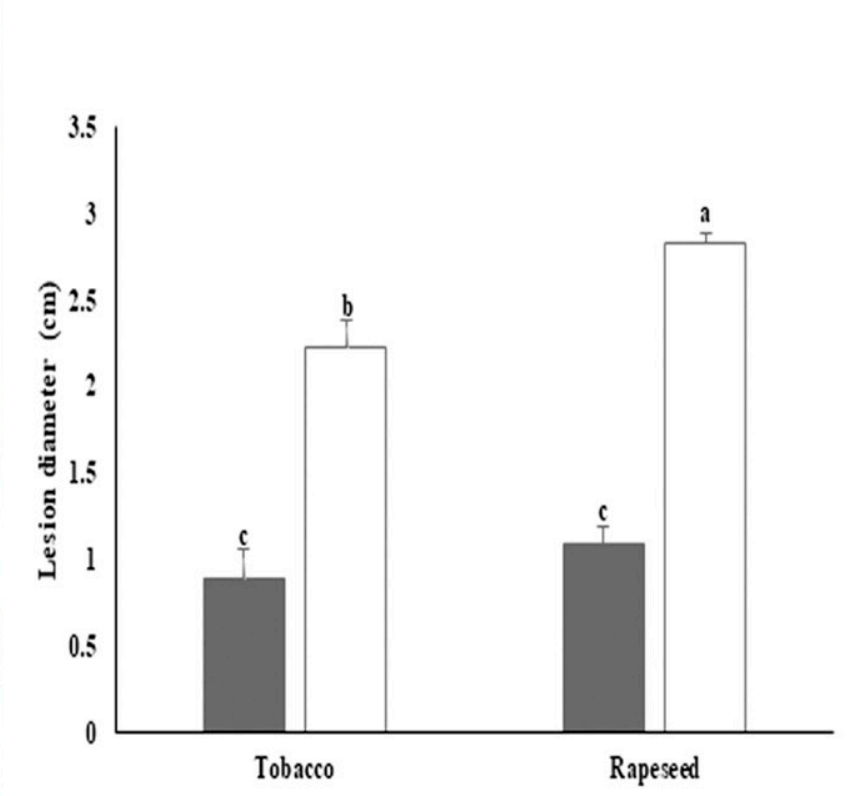

Treated

$\square$ Control

Fig. 6. Effect of Bacillus amyloliquefaciens EZ1509 on pathogenicity of Sclerotinia sclerotiorum. A, Pathogenicity assay on detached rapeseed and tobacco leaves. B, Effect of B. amyloliquefaciens EZ1509 on lesion diameter compared with untreated control. Means with similar letters are not statistically different from each other as analyzed by Tukey's honestly significant difference test at $P \leq 0.05$. Error bars represent standard error \pm standard error of the mean.

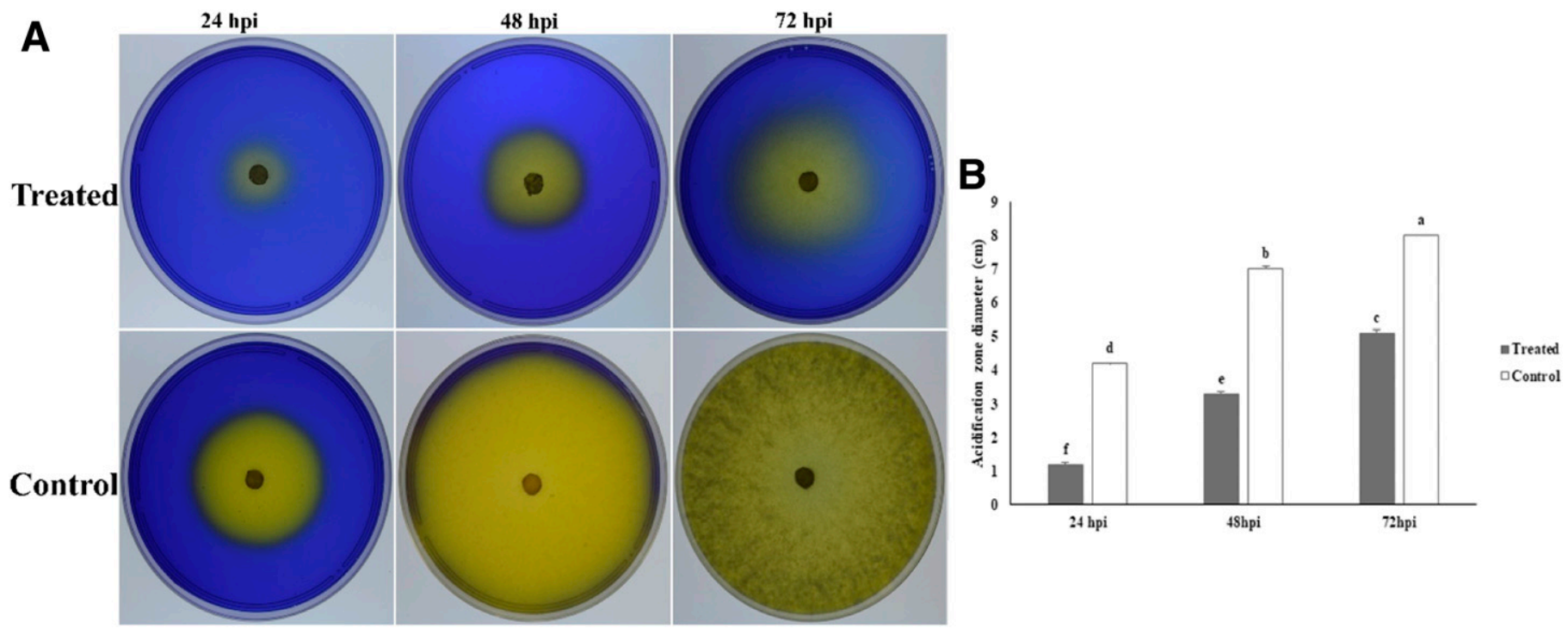

Fig. 7. Effect of Bacillus amyloliquefaciens EZ1509 on acidification zone indicative of oxalic acid by Sclerotinia sclerotiorum. A, Plate assay amended with bromophenol blue. B, Diameter of acidification zone indicating oxalic acid production under influence of B. amyloliquefaciens EZ1509 at different time intervals in hours postinoculation (hpi) compared with untreated control. Means with similar letters are not statistically different from each other as analyzed by Tukey's honestly significant difference test at $P \leq 0.05$. Error bars represent standard error \pm standard error of the mean. 
(2016) observed plasmolysis and shrinkage of fungal hyphae of $L$. theobromae in the inhibition zone during antagonism assay owing to antifungal LPs produced by B. subtilis B1.

Oxalic acid is considered as a primary determinant of pathogenicity of S. sclerotiorum (Bolton et al. 2006; Godoy et al. 1990). S. sclerotiorum initiates the production of oxalic acid to create a conducive environment for the release of hydrolytic enzymes. We hypothesized that B. amyloliquefaciens EZ1509 might influence oxalic acid production by $S$. sclerotiorum as a result of antagonistic interaction. Bromophenol blue test indicated reduced acidification, which is indicative of reduced oxalic acid production by $S$. sclerotiorum challenged with $B$. amyloliquefaciens EZ1509 compared with control. The inhibitory activity of B. amyloliquefaciens EZ1509 on pathogenicity of S. sclerotiorum is an indication of weak compatibility between Bacillus-treated pathogen and host tissues. The weak interaction between host and pathogen might be owing to the inability of S. sclerotiorum to produce oxalic acid. Massawe et al. (2018) reported that volatile organic compounds (VOCs) emitted by Bacillus species altered the ability of $S$. sclerotiorum to release oxalic acid and reduced the pathogenicity level to the assayed host plants. However, unlike their study, we have associated the reduced pathogenicity of $S$. sclerotiorum with the effect of diffusible antifungal LPs producing B. amyloliquefaciens instead of VOCs.

$S$. sclerotiorum contains a plethora of virulence-related genes that are directly involved in pathogenicity. During host penetration and subsequent infection stages, the fungus must break the layers of host defense barriers. To achieve this goal, the fungus produces a cocktail of hydrolytic enzymes, effector proteins, and secondary metabolites. OAH is a key hydrolytic enzyme that coverts oxaloacetate to oxalic acid. Oxalic acid is secreted in early events of fungal infection, and it is crucial for the suppression of host defense (Moosa et al. 2018; Williams et al. 2011). Disruption of the OAH gene in $S$. sclerotiorum leads to reduced virulence (Liang et al. 2015). Genes encoding acid protease and aspartyl protease in $S$. sclerotiorum are involved in the decomposition of host defense proteins at early stages of infection (Poussereau et al. 2001) and cell death (Movahedi and Heale 1990). Endopolygalacturonase enzymes cause degradation of cell wall pectin and lysis of fungal hyphae (Kazemi-Pour et al. 2004; Moosa et al. 2018; Reymond et al. 1994). Hyphal deformities, inability to produce oxalic acid, and reduced pathogenicity of $S$. sclerotiorum provoked us to study the effect of bacterial antagonist on pathogenicity-related genes of the fungal pathogen. The results revealed that the expression of virulence genes was significantly reduced in fungal mycelium previously challenged with B. amyloliquefaciens EZ1509 in dual culture. To the best of our knowledge, current study is the first report of reduced expression of virulence-linked genes in

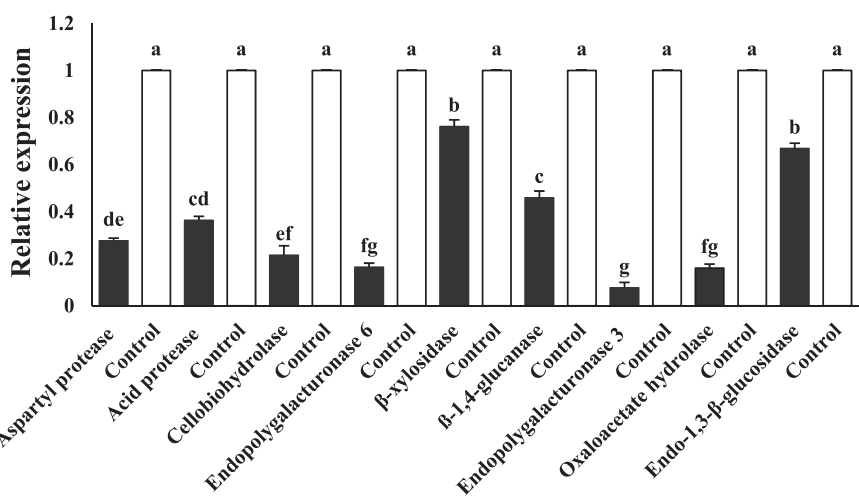

Fig. 8. Effect of Bacillus amyloliquefaciens EZ1509 on expression of virulence genes of Sclerotinia sclerotiorum. Means with similar letters are not statistically different from each other as analyzed by Tukey's honestly significant difference test at $P \leq 0.05$. Error bars represent standard error \pm standard error of the mean.
S. sclerotiorum challenged with the bacterial antagonist in a dual culture assay. Previously, the VOCs produced by the genus Bacillus altered the expression of several virulence genes of Ralstonia solanacearum and reduced the incidence of wilt disease (Tahir et al. 2017).

Bacteria use different mechanisms to control fungal pathogens, but we hypothesized that diffusible LPs are the main antifungal weapon of B. amyloliquefaciens EZ1509 during direct antifungal activity against $S$. sclerotiorum. Mutants of $B$. amyloliquefaciens $\mathrm{C} 06$ and B. amyloliquefaciens FZB42 deficient in one or more LPs biosynthetic genes lost their antifungal activity against fungal pathogens in dual-culture assay (Cawoy et al. 2014; Gu et al. 2017; Liu et al. 2011). In a comparative study with six B. subtilis/B. amyloliquefaciens strains, the antifungal activity of the strains was found to be connected with their ability to synthesize cyclic LPs (Chowdhury et al. 2015). Moreover, an increase in the production of fengycin and iturin by B. amyloliquefaciens has been observed in the presence of certain plant pathogens (Cawoy et al. 2015).

Conclusively, B. amyloliquefaciens EZ1509 can perceive specific elicitors molecules emitted by the pathogen, and it can upregulate the biosynthesis of LPs. Our study shows that the bacterium produces different LPs (fengycin, iturin, surfactin, and bacilysin) during cocultivation with the fungus, and this cocultivation led to deteriorations in fungal mycelium, reduced pathogenicity, and downregulation of virulence genes on coculturing. Hence, we infer the conclusion that B. amyloliquefaciens EZ1509 can be considered as a very effective biocontrol agent to minimize the destructive effects of $S$. sclerotiorum on host plants.

\section{LITERATURE CITED}

Arrebola, E., Jacobs, R., and Korsten, L. 2010. Iturin A is the principal inhibitor in the biocontrol activity of Bacillus amyloliquefaciens PPCB004 against postharvest fungal pathogens. J. Appl. Microbiol. 108:386-395.

Athukorala, S. N., Fernando, W. D., and Rashid, K. Y. 2009. Identification of antifungal antibiotics of Bacillus species isolated from different microhabitats using polymerase chain reaction and MALDI-TOF mass spectrometry. Can. J. Microbiol. 55:1021-1032.

Bloomfield, B., and Alexander, M. 1967. Melanins and resistance of fungi to lysis. J. Bacteriol. 93:1276-1280.

Boland, G., and Hall, R. 1987. Epidemiology of white mold of white bean in Ontario. Can. J. Plant Pathol. 9:218-224.

Boland, G., and Hall, R. 1994. Index of plant hosts of Sclerotinia sclerotiorum. Can. J. Plant Pathol. 16:93-108.

Bolton, M. D., Thomma, B. P., and Nelson, B. D. 2006. Sclerotinia sclerotiorum (Lib.) de Bary: Biology and molecular traits of a cosmopolitan pathogen. Mol. Plant Pathol. 7:1-16.

Brogden, K. A. 2005. Antimicrobial peptides: Pore formers or metabolic inhibitors in bacteria? Nat. Rev. Microbiol. 3:238-250.

Cawoy, H., Debois, D., Franzil, L., De Pauw, E., Thonart, P., and Ongena, M. 2015. Lipopeptides as main ingredients for inhibition of fungal phytopathogens by Bacillus subtilis/amyloliquefaciens. Microb. Biotechnol. 8: 281-295.

Cawoy, H., Mariutto, M., Henry, G., Fisher, C., Vasilyeva, N., Thonart, P., Dommes, J., and Ongena, M. 2014. Plant defense stimulation by natural isolates of Bacillus depends on efficient surfactin production. Mol. PlantMicrobe Interact. 27:87-100.

Chen, X., Koumoutsi, A., Scholz, R., Schneider, K., Vater, J., Süssmuth, R., Piel, J., and Borriss, R. 2009. Genome analysis of Bacillus amyloliquefaciens FZB42 reveals its potential for biocontrol of plant pathogens. J. Biotechnol. 140:27-37.

Chowdhury, S. P., Hartmann, A., Gao, X. W., and Borriss, R. 2015. Biocontrol mechanism by root-associated Bacillus amyloliquefaciens FZB42 - a review. Front. Microbiol. 6:780.

Condon, C. 2003. RNA processing and degradation in Bacillus subtilis. Microbiol. Mol. Biol. Rev. 67:157-174.

Debois, D., Jourdan, E., Smargiasso, N., Thonart, P., De Pauw, E., and Ongena, M. 2014. Spatiotemporal monitoring of the antibiome secreted by Bacillus biofilms on plant roots using MALDI mass spectrometry imaging. Anal. Chem. 86:4431-4438.

Deleu, M., Paquot, M., Nylander, T., and Science, I. 2005. Fengycin interaction with lipid monolayers at the air-aqueous interface-implications for the effect of fengycin on biological membranes. J. Colloid Interface Sci. 283:358-365. 
Deutscher, M. P. 2006. Degradation of RNA in bacteria: Comparison of mRNA and stable RNA. Nucleic Acids Res. 34:659-666.

Dimkić, I., Stanković, S., Nišavić, M., Petković, M., Ristivojević, P., Fira, D., and Berić, T. 2017. The profile and antimicrobial activity of Bacillus lipopeptide extracts of five potential biocontrol strains. Front. Microbiol. 8: 925.

Emmert, E. A., and Handelsman, J. 1999. Biocontrol of plant disease: A (Gram-) positive perspective. FEMS Microbiol. Lett. 171:1-9.

Farzand, A., Moosa, A., Zubair, M., Khan, A. R., Hanif, A., Tahir, H. A. S., and Gao, X. 2019. Marker assisted detection and LC-MS analysis of antimicrobial compounds in different Bacillus strains and their antifungal effect on Sclerotinia sclerotiorum. Biol. Control 133:91-102.

Garbeva, P., Silby, M. W., Raaijmakers, J. M., Levy, S. B., and De Boer, W. 2011. Transcriptional and antagonistic responses of Pseudomonas fluorescens $\mathrm{Pf0}-1$ to phylogenetically different bacterial competitors. ISME J. 5:973-985.

Godoy, G., Steadman, J. R., Dickman, M. B., and Dam, R. 1990. Use of mutants to demonstrate the role of oxalic acid in pathogenicity of Sclerotinia sclerotiorum on Phaseolus vulgaris. Physiol. Mol. Plant Pathol. 37: 179-191.

Grabova, A. Y., Dragovoz, I., Zelena, L., Tkachuk, D., and Avdeeva, L. 2016. Antifungal activity and gene expression of lipopeptide antibiotics in strains of genus Bacillus. Biopolymers Cell 32:41-48.

Gu, Q., Yang, Y., Yuan, Q., Shi, G., Wu, L., Lou, Z., Huo, R., Wu, H., Borriss, R., and Gao, X. 2017. Bacillomycin D produced by Bacillus amyloliquefaciens is involved in the antagonistic interaction with the plant pathogenic fungus Fusarium graminearum. Appl. Environ. Microbiol. 83:AEM.0107501017 .

Hobley, L., Ostrowski, A., Rao, F. V., Bromley, K. M., Porter, M., Prescott, A. R., MacPhee, C. E., Van Aalten, D. M., and Stanley-Wall, N. R. 2013. BslA is a self-assembling bacterial hydrophobin that coats the Bacillus subtilis biofilm. Proc. Nat. Acad. Sci. 110:13600-13605.

Hofemeister, J., Conrad, B., Adler, B., Hofemeister, B., Feesche, J., Kucheryava, N., Steinborn, G., Franke, P., Grammel, N., Zwintscher, A., Leenders, F., Hitzeroth, G., and Vater, J. 2004. Genetic analysis of the biosynthesis of non-ribosomal peptide- and polyketide-like antibiotics, iron uptake and biofilm formation by Bacillus subtilis A1/3. Mol. Genet. Genomics 272:363-378.

Johnson, L. F., and Curl, E. A. 1972. Methods for Research on the Ecology of Soil-Borne Plant Pathogens. Burgess Publishing Co., Minneapolis, MN

Jordan, et al. 2006.

Kamal, M. M., Savocchia, S., Lindbeck, K. D., and Ash, G. J. 2016. Biology and biocontrol of Sclerotinia sclerotiorum (Lib.) de Bary in oilseed Brassicas. Austral. Plant Pathol. 45:1-14.

Kazemi-Pour, N., Condemine, G., and Hugouvieux-Cotte-Pattat, N. 2004. The secretome of the plant pathogenic bacterium Erwinia chrysanthemi. Proteomics 4:3177-3186.

Kim, K. S., Min, J.-Y., and Dickman, M. B. 2008. Oxalic acid is an elicitor of plant programmed cell death during Sclerotinia sclerotiorum disease development. Mol. Plant-Microbe Interact. 21:605-612.

Kim, P. I., Bai, H., Bai, D., Chae, H., Chung, S., Kim, Y., Park, R., and Chi, Y. T. 2004. Purification and characterization of a lipopeptide produced by Bacillus thuringiensis CMB26. J. Appl. Microbiol. 97:942-949.

Kim, P. I., Ryu, J., Kim, Y. H., and Chi, Y.-T. 2010. Production of biosurfactant lipopeptides Iturin A, fengycin and surfactin A from Bacillus subtilis CMB32 for control of Colletotrichum gloeosporioides. J. Microbiol. Biotechnol. 20:138-145.

Kumar, P., Dubey, R., and Maheshwari, D. 2012. Bacillus strains isolated from rhizosphere showed plant growth promoting and antagonistic activity against phytopathogens. Microbiol. Res. 167:493-499.

Li, B., Li, Q., Xu, Z., Zhang, N., Shen, Q., and Zhang, R. 2014. Responses of beneficial Bacillus amyloliquefaciens SQR9 to different soilborne fungal pathogens through the alteration of antifungal compounds production. Front. Microbiol. 5:636.

Liang, X., Liberti, D., Li, M., Kim, Y. T., Hutchens, A., Wilson, R., and Rollins, J. A. 2015. Oxaloacetate acetylhydrolase gene mutants of Sclerotinia sclerotiorum do not accumulate oxalic acid, but do produce limited lesions on host plants. Mol. Plant Pathol. 16:559-571.

Liu, J., Zhou, T., He, D., Li, X., Wu, H., Liu, W., and Gao, X. 2011. Functions of lipopeptides bacillomycin D and fengycin in antagonism of Bacillus amyloliquefaciens C06 towards Monilinia fructicola. J. Mol. Microbiol. Biotechnol. 20:43-52.

Livak, K. J., and Schmittgen, T. D. 2001. Analysis of relative gene expression data using real-time quantitative PCR and the $2-\Delta \Delta C T$ method. J. Methods 25:402-408

Maget-Dana, R., and Peypoux, F. 1994. Iturins, a special class of pore-forming lipopeptides: Biological and physicochemical properties. Toxicology 87: 151-174.
Maget-Dana, R., Thimon, L., Peypoux, F., and Ptak, M. 1992. Surfactin/iturin A interactions may explain the synergistic effect of surfactin on the biological properties of iturin A. Biochimie 74:1047-1051.

Malfanova, N., Franzil, L., Lugtenberg, B., Chebotar, V., and Ongena, M. 2012. Cyclic lipopeptide profile of the plant-beneficial endophytic bacterium Bacillus subtilis HC8. Arch. Microbiol. 194:893-899.

Massawe, V. C., Hanif, A., Farzand, A., Mburu, D. K., Ochola, S. O., Wu, L., Tahir, H. A. S., Gu, Q., Wu, H., and Gao, X. 2018. Volatile compounds of endophytic Bacillus spp. have biocontrol activity against Sclerotinia sclerotiorum. Phytopathology 108:1373-1385.

Minuto, A., Spadaro, D., Garibaldi, A., and Gullino, M. L. 2006. Control of soilborne pathogens of tomato using a commercial formulation of Streptomyces griseoviridis and solarization. Crop Prot. 25:468-475.

Moosa, A., Farzand, A., Sahi, S. T., and Khan, S. A. 2018. Transgenic expression of antifungal pathogenesis-related proteins against phytopathogenic fungi -15 years of success. Isr. J. Plant Sci. 65:38-54.

Movahedi, S., and Heale, J. B. 1990. The roles of aspartic proteinase and endopectin lyase enzymes in the primary stages of infection and pathogenesis of various host tissues by different isolates of Botrytis cinerea Pers ex. Pers. Physiol. Mol. Plant Pathol. 36:303-324.

Nihorimbere, V., Cawoy, H., Seyer, A., Brunelle, A., Thonart, P., and Ongena, M. 2012. Impact of rhizosphere factors on cyclic lipopeptide signature from the plant beneficial strain $B$ acillus amyloliquefaciens S499. FEMS Microbiol. Ecol. 79:176-191.

Ongena, M., and Jacques, P. 2008. Bacillus lipopeptides: Versatile weapons for plant disease biocontrol. Trends Microbiol. 16:115-125.

Ongena, M., Jourdan, E., Adam, A., Paquot, M., Brans, A., Joris, B., Arpigny, J.-L., and Thonart, P. 2007. Surfactin and fengycin lipopeptides of Bacillus subtilis as elicitors of induced systemic resistance in plants. Environ. Microbiol. 9:1084-1090.

Pan, C., Xu, S., Zhou, H., Fu, Y., Ye, M., and Zou, H. 2007. Recent developments in methods and technology for analysis of biological samples by MALDI-TOF-MS. Anal. Bioanal. Chem. 387:193-204.

Pathak, K. V., and Keharia, H. 2014. Identification of surfactins and iturins produced by potent fungal antagonist, Bacillus subtilis $\mathrm{K} 1$ isolated from aerial roots of banyan (Ficus benghalensis) tree using mass spectrometry. Biotech 4:283-295.

Poussereau, N., Gente, S., Rascle, C., Billon-Grand, G., and Fèvre, M. 2001. aspS encoding an unusual aspartyl protease from Sclerotinia sclerotiorum is expressed during phytopathogenesis. FEMS Microbiol. Lett. 194:27-32.

Price, N. P., Rooney, A. P., Swezey, J. L., Perry, E., and Cohan, F. M. 2007. Mass spectrometric analysis of lipopeptides from Bacillus strains isolated from diverse geographical locations. FEMS Microbiol. Lett. 271:83-89.

Purdy, L. H. 1979. Sclerotinia sclerotiorum: History, diseases and symptomatology, host range, geographic distribution, and impact. Phytopathology 69:875-880.

Raaijmakers, J. M., De Bruijn, I., Nybroe, O., and Ongena, M. 2010. Natural functions of lipopeptides from Bacillus and Pseudomonas: More than surfactants and antibiotics. FEMS Microbiol. Rev. 34:1037-1062.

Rahman, M. M. E., Hossain, D. M., Suzuki, K., Shiiya, A., Suzuki, K., Dey, T. K., Nonaka, M., and Harada, N. 2016. Suppressive effects of Bacillus spp. on mycelia, apothecia and sclerotia formation of Sclerotinia sclerotiorum and potential as biological control of white mold on mustard. Austral. Plant Pathol. 45:103-117.

Reymond, P., Deléage, G., Rascle, C., and Fèvre, M. 1994. Cloning and sequence analysis of a polygalacturonase-encoding gene from the phytopathogenic fungus Sclerotinia sclerotiorum. Gene 146:233-237.

Romero, D., de Vicente, A., Rakotoaly, R. H., Dufour, S. E., Veening, J.-W., Arrebola, E., Cazorla, F. M., Kuipers, O. P., Paquot, M., and Pérez-García, A. 2007. The iturin and fengycin families of lipopeptides are key factors in antagonism of Bacillus subtilis toward Podosphaera fusca. Mol. PlantMicrobe Interact. 20:430-440.

Sajitha, K., and Dev, S. A. 2016. Quantification of antifungal lipopeptide gene expression levels in Bacillus subtilis B1 during antagonism against sapstain fungus on rubberwood. Biol. Control 96:78-85.

Sajitha, K., Dev, S. A., and Florence, E. M. 2016. Identification and characterization of lipopeptides from Bacillus subtilis B1 against sapstain fungus of rubberwood through MALDI-TOF-MS and RT-PCR. Curr. Microbiol. 73:46-53.

Sharma, N., and Sharma, S. 2008. Control of foliar diseases of mustard by Bacillus from reclaimed soil. Microbiol. Res. 163:408-413.

Silva, A. P. D., Bolton, M. D., and Nelson, B. D. 2009. Transformation of Sclerotinia sclerotiorum with the green fluorescent protein gene and fluorescence of hyphae in four inoculated hosts. Plant Pathol. 58:487-496.

Souto, G., Correa, O., Montecchia, M., Kerber, N., Pucheu, N., Bachur, M., and Garcia, A. 2004. Genetic and functional characterization of a Bacillus sp. strain excreting surfactin and antifungal metabolites partially identified as iturin-like compounds. J. Appl. Microbiol. 97:1247-1256. 
Steadman, J., Marcinkowska, J., and Rutledge, S. 1994. A semi-selective medium for isolation of Sclerotinia sclerotiorum. Can. J. Plant Pathol. 16: 68-70.

Stein, T. 2005. Bacillus subtilis antibiotics: Structures, syntheses and specific functions. Mol. Microbiol. 56:845-857.

Susi, P., Aktuganov, G., Himanen, J., and Korpela, T. 2011. Biological control of wood decay against fungal infection. J. Environ. Manage. 92: 1681-1689.

Tahir, H. A. S., Gu, Q., Wu, H., Niu, Y., Huo, R., and Gao, X. 2017. Bacillus volatiles adversely affect the physiology and ultra-structure of Ralstonia solanacearum and induce systemic resistance in tobacco against bacterial wilt. Sci. Rep. 7:40481.

Torres, M. J., Brandan, C. P., Petroselli, G., Erra-Balsells, R., and Audisio, M. C. 2016. Antagonistic effects of Bacillus subtilis subsp. subtilis and B. amyloliquefaciens against Macrophomina phaseolina: SEM study of fungal changes and UV-MALDI-TOF MS analysis of their bioactive compounds. Microbiol. Res. 182:31-39.

Vanittanakom, N., Loeffler, W., Koch, U., and Jung, G. 1986. Fengycin-a novel antifungal lipopeptide antibiotic produced by Bacillus subtilis F-29-3. J. Antibiot. 39:888-901.

Vater, J., Gao, X., Hitzeroth, G., Wilde, C., and Franke, P. 2003. "Whole cell”matrix-assisted laser desorption ionization-time of flight-mass spectrometry, an emerging technique for efficient screening of biocombinatorial libraries of natural compounds-present state of research. Comb. Chem. High Throughput Screen. 6:557-567.

Vater, J., Kablitz, B., Wilde, C., Franke, P., Mehta, N., and Cameotra, S. S. 2002. Matrix-assisted laser desorption ionization-time of flight mass spectrometry of lipopeptide biosurfactants in whole cells and culture filtrates of Bacillus subtilis $\mathrm{C}-1$ isolated from petroleum sludge. Appl. Environ. Microbiol. 68:6210-6219.

Velho, R. V., Caldas, D. G. G., Medina, L. F. C., Tsai, S. M., and Brandelli, A. 2011. Real-time PCR investigation on the expression of sboA and ituD genes in Bacillus spp. Lett. Appl. Microbiol. 52:660-666.

Wang, S., Wu, H., Zhan, J., Xia, Y., Gao, S., Wang, W., Xue, P., and Gao, X. 2011. The role of synergistic action and molecular mechanism in the effect of genetically engineered strain Bacillus subtilis OKBHF in enhancing tomato growth and Cucumber mosaic virus resistance. BioControl 56:113-121.

Whipps, J. M. 2001. Microbial interactions and biocontrol in the rhizosphere. J. Exp. Bot. 52:487-511.

Williams, B., Kabbage, M., Kim, H.-J., Britt, R., and Dickman, M. B. 2011. Tipping the balance: Sclerotinia sclerotiorum secreted oxalic acid suppresses host defenses by manipulating the host redox environment. PLoS Pathog 7: e1002107.

Wu, L., Wu, H., Chen, L., Lin, L., Borriss, R., and Gao, X. 2015a. Bacilysin overproduction in Bacillus amyloliquefaciens FZB42 markerless derivative strains FZBREP and FZBSPA enhances antibacterial activity. Appl. Microbiol. 99:4255-4263.

Wu, L., Wu, H., Chen, L., Yu, X., Borriss, R., and Gao, X. 2015b. Difficidin and bacilysin from Bacillus amyloliquefaciens FZB42 have antibacterial activity against Xanthomonas oryzae rice pathogens. Sci. Rep. 5:12975.

Yang, D., Wang, B., Wang, J., Chen, Y., and Zhou, M. 2009. Activity and efficacy of Bacillus subtilis strain NJ-18 against rice sheath blight and Sclerotinia stem rot of rape. Biol. Control 51:61-65.

Zhang, S. M., Wang, Y. X., Meng, L. Q., Li, J., Zhao, X. Y., Cao, X., Chen, X. L., Wang, A. X., and Li, J. F. 2012. Isolation and characterization of antifungal lipopeptides produced by endophytic Bacillus amyloliquefaciens TF28. Afr. J. Microbiol. Res. 6:1747-1755.

Zhao, P., Quan, C., Wang, Y., Wang, J., and Fan, S. 2014. Bacillus amyloliquefaciens Q-426 as a potential biocontrol agent against Fusarium oxysporum f. sp. spinaciae. J. Basic Microbiol. 54:448-456.

Zhu, Z., Li, R., Yu, G., Ran, W., and Shen, Q. 2013. Enhancement of lipopeptides production in a two-temperature-stage process under SSF conditions and its bioprocess in the fermenter. Bioresour. Technol. 127: 209-215.

Zihalirwa Kulimushi, P., Argüelles Arias, A., Franzil, L., Steels, S., and Ongena, M. 2017. Stimulation of fengycin-type antifungal lipopeptides in Bacillus amyloliquefaciens in the presence of the maize fungal pathogen Rhizomucor variabilis. Front. Microbiol. 8:850.

Zokaeifar, H., Babaei, N., Saad, C. R., Kamarudin, M. S., Sijam, K., and Balcázar, J. L. 2014. Detection and identification of antibiotic biosynthesis genes in Bacillus subtilis strains. Biocontrol Sci. Tech. 24:233-240. 